\section{Stany Zjednoczone i Unia Europejska jako promotorzy reform demokratycznych w państwach Bliskiego Wschodu i Afryki Północnej w pierwszej dekadzie XXI wieku}

\begin{abstract}
Streszczenie: Zarówno Stany Zjednoczone, jak i Unia Europejska prowadzą aktywną politykę wobec państw Bliskiego Wschodu i Afryki Północnej. Od początku lat 90. XX wieku jednym z istotnych elementów działań politycznych tych dwóch ważnych aktorów sceny międzynarodowej są inicjatywy, mające na celu wspieranie procesów demokratyzacyjnych. Unia Europejska i Stany Zjednoczone są autorami szeregu programów polityczno-gospodarczych, których beneficjentami są państwa regionu. W artykule przeanalizowano i porównano najważniejsze programy autorstwa Stanów Zjednoczonych [United States Agency for International Development (USAID), Human Rights and Democracy Fund, Middle East Partnership Initiative (MEPI), The Greater Middle East Initiative oraz Broader Middle East and North Africa Initiative (BMENAI)] i Unii Europejskiej [Europejska Inicjatywa na Rzecz Demokracji i Praw Człowieka (od 2007 roku Europejski Instrument na Rzecz Demokracji i Praw Człowieka), Partnerstwo Eurośródziemnomorskie oraz Europejska Polityka Sąsiedztwa].
\end{abstract}

Słowa kluczowe: Bliski Wschód, Afryka Północna, Stany Zjednoczone, Unia Europejska, demokracja

\begin{abstract}
„The survival of liberty in our land increasingly depends on the success of liberty in other lands. The best hope for peace in our world is the expansion of freedom in all the world".
\end{abstract}

(Bush, 2005)

\footnotetext{
Crije elem artykułu jest przedstawienie i porównanie polityki Unii Europejskiej i Stanów Zjednoczonych wobec państw Bliskiego Wschodu i Afryki Północnej do 2010 roku. Unia Europejska i Stany Zjednoczone są autorami szeregu programów polityczno-gospodarczych, których beneficjentami są państwa regionu. Kluczową rolę w tych programach odgrywały kwestie związane z demokratyzacją życia politycznego w państwach arabskich. Analiza polityki Unii Europejskiej i Stanów Zjednoczonych w zakresie wspierania procesów demokratyzacyjnych na obszarze Afryki Północnej i Bliskiego Wschodu zostanie przeprowadzona w oparciu o najważniejsze programy pomocowe. Do instrumentów, za pomocą których Unia Europejska realizowała swoją politykę wobec państw regionu zaliczyć należy: Europejską Inicjatywę na Rzecz Demokracji i Praw Człowieka (od 2007 roku Europejski Instrument na Rzecz Demokracji i Praw Człowieka), Partnerstwo Eurośródziemnomorskie oraz Europejską Politykę Sąsiedztwa. Jakkolwiek trzeba podkreślić, iż działania na rzecz demokratyzacji państw regionu śródziemnomorskiego podejmowały nie tylko instytucje Unii Europejskiej, ale również poszczególne państwa członkowskie w sposób indywidualny, np. Francja. Powyższe inicjatywy różniły się za-
} 
kresem zadań, podmiotami, do których były adresowane, a także sposobami realizacji. Z kolei do najważniejszych instrumentów polityki Stanów Zjednoczonych zaliczyć należy: United States Agency for International Development (USAID), Human Rights and Democracy Fund (HRDF), Middle East Partnership Initiative (MEPI), The Greater Middle East Initiative (GMEI) oraz Broader Middle East and North Africa Initiative (BMENAI).

Po zakończeniu zimnej wojny problem rozwoju demokracji w państwach Afryki Północnej i Bliskiego Wschodu stał się ważny dla klasy politycznej cywilizacji zachodniej, zarówno europejskiej, jak i amerykańskiej (Huber, 2008, s. 44). O rosnącym znaczeniu działań, wspierających programy demokratyzacyjne w różnych częściach świata, również w regionie śródziemnomorskim, w polityce najważniejszych uczestników współczesnych stosunków międzynarodowych świadczy widoczny wzrost środków finansowych przeznaczonych na realizację powyższych zadań. Przykładowo budżet United States Agency for International Development (USAID) wzrósł z 106 mln USD w roku 1990 do 830 mln USD w 2004 roku (Finkel, Perez-Linan, Seligson, 2006, s. 26). Z kolei budżet European Initiative for Democracy and Human Rights (EIDHR) wzrósł z $76 \mathrm{mln}$ ecu w 1995 roku do 132 mln euro w 2006 roku. Od 2001 roku państwa członkowskie Unii Europejskiej przeznaczają na promocję demokracji kwotę $900 \mathrm{mln}$ euro rocznie (Youngs, 2003, s. 128).

Co prawda zarówno Europejczycy, jak i Amerykanie wspieranie procesów demokratyzacyjnych w różnych częściach świata definiują podobnie, to dostrzec można pewne różnice zwłaszcza $\mathrm{w}$ technicznej stronie realizacji zadań o tym charakterze. Różnice w określeniu priorytetów w zakresie wspierania procesów demokratycznych przez Europejczyków i Amerykanów można tłumaczyć doświadczeniami historycznymi. W przypadku Stanów Zjednoczonych zręby systemu demokratycznego tworzono przed powstaniem instytucji państwa amerykańskiego. W Europie odwrotnie, najpierw istniały państwa, a następnie rodziła się demokracja (Nau, 2000, s. 147). Zdaniem przedstawicieli USAID promocja demokracji na świecie polega w pierwszej kolejności na: ,udzielaniu technicznej i finansowej pomocy i każdego innego wsparcia dla zwiększenia możliwości działania proreformatorskich władz danego państwa, dla organizacji pozarządowych oraz nawet pojedynczych obywateli, którzy działają na rzecz rozwoju demokracji. Programy demokratyzacyjne mają promować zasadę praworządności, prawa człowieka, transparentność i uczciwość wyborów, rozwój wolnych mediów, budowę społeczeństwa obywatelskiego i last but not least zachęcać obywateli do jak najszerszego uczestnictwa w wyborach parlamentarnych czy lokalnych, a przez to aktywnie partycypować w tworzeniu struktur i instytucji państwa" (USAID, 2005, s. 4). Według Komisji Europejskiej definicja demokratyzacji państw trzecich sprowadza się do: „wspierania demokratycznego uczestnictwa obywateli w życiu politycznym państwa (wolne wybory, system wielopartyjny, partycypacja obywateli w podejmowaniu decyzji), podstawowych praw człowieka (wolności obywatelskich, wolność wypowiedzi i stowarzyszania się, ratyfikacja konwencji i traktatów międzynarodowych z zakresu ochrony praw człowieka), rządów prawa (niezależne sądownictwo, stosowanie się policji i urzędników administracji publicznej do obowiązującego prawa, równość obywateli wobec prawa)" (European Commission, 2003, s. 10). 


\section{Unia Europejska}

Początki polityki Unii Europejskiej, wspierającej procesy demokratyzacyjne w państwach Afryki Północnej i Bliskiego Wschodu sięgają połowy lat 90. XX wieku. Jako pierwszą wymienić należy powołaną do życia przez Parlament Europejski w 1994 roku Europejską Inicjatywę na Rzecz Demokracji i Praw Człowieka (European Initiative for Democracy and Human Rights, EIDHR), która od 2007 roku przyjęła nazwę Europejski Instrument na Rzecz Demokracji i Praw Człowieka. Od 1999 roku EIDHR jest częścią The Europe Aid Cooperation Office. W 1995 roku budżet programu ustalono na kwotę 75,96 mln ECU rocznie, zwiększając go od 2006 roku do 132,125 mln euro (European Commission, 2006, s. 11). Europejska Inicjatywa na Rzecz Demokracji i Praw Człowieka była projektem, który w przeciwieństwie do innych programów UE miał za zadanie tylko i wyłącznie promować rozwiązania demokratyczne wśród społeczeństw państw - beneficjentów. W przypadku późniejszych projektów tj. Partnerstwa Eurośródziemnomorskiego czy Europejskiej Polityki Sąsiedztwa jedynie pojawiały się elementy demokratyzacyjne wśród innych zadań np. z zakresu bezpieczeństwa ekonomicznego, energetycznego lub przeciwdziałania nielegalnej imigracji. Kolejny element, wyróżniający ten program spośród innych programów autorstwa Unii Europejskiej polegał na tym, iż EIDHR nie wymaga zgody na działanie ze strony rządów państw beneficjentów. Był skierowany bezpośrednio do organizacji pozarządowych w celu tworzenia fundamentów społeczeństwa obywatelskiego (the civil society programme). W latach 1996-1999 największymi beneficjentami EIDHR były Izrael i Autonomia Palestyńska. Palestyńczycy otrzymali środki finansowe w wysokości 160 euro w przeliczeniu na jednego mieszkańca, co stanowiło $20 \%$ całości budżetu EIDHR. W przypadku Izraela suma wynosiła 60 euro per capita tj. 16\% budżetu projektu. Znaczące środki skierowano nieprzypadkowo do tych dwóch partnerów. Konflikt palestyńsko-izraelski ma miejsce w bezpośrednim sąsiedztwie Unii Europejskiej. Pozostali beneficjenci programu to: Jordania, Liban, a także w symbolicznym wymiarze Algieria, Maroko, Egipt, Syria i Tunezja. W 2002 roku Unia Europejska zdecydowała o sfinansowaniu projektów demokratyzacyjnych w ramach EIDHR w wybranych państwach regionu. Kryteriami wyboru okazały się ,potencjalne możliwości budowy społeczeństwa obywatelskiego, stan dialogu politycznego, dotychczasowego poziomu współpracy z Unią Europejską i z poszczególnymi państwami członkowskimi UE" (Huber, 2008, s. 56).

Do wybranej grupy państw zaliczono: Algierię, Tunezję, Izrael i Autonomię Palestyńską. Ze względu na krytykę tej ograniczonej formy współpracy oraz braku środków finansowych skierowanych do organizacji pozarządowych w regionie Unia Europejska w 2004 roku powróciła do realizacji EIDHR w pierwotnej formie (Holden, 2005, s. 473). Ramowy zakres tematyczny projektu obejmował następujące cele: pluralizm w świecie mediów, prawa kobiet i prawa człowieka, działanie na rzecz zniesienia kary śmierci, zaprzestanie stosowania tortur, walka z rasizmem i ksenofobią. Spośród szczegółowych zadań programu warto wymienić: organizację serii seminariów na temat utworzenia wolnych mediów i wspierania niezależnych dziennikarzy, kampanię na rzecz zaprzestania okaleczania żeńskich narządów płciowych/obrzezania w Egipcie, instalację monitoringu w zakładach karnych, poprawienie warunków życia w więzieniach i przestrzeganie praw 
osadzonych. W Izraelu w ramach EIDHR przeprowadzono kampanię edukacyjno-informacyjną wśród społeczeństwa i decydentów dotycząca przestrzegania praw człowieka, która polegała na przeszkoleniu aktywistów izraelskich organizacji pozarządowych. Osobny sektor dotyczył pomocy skierowanej do Palestyńczyków. W latach 2003-2008 dzięki programowi EIDHR monitorowano wybory prezydenckie i parlamentarne na terenie Autonomii Palestyńskiej. Realizacja tego zadania pochłonęła $17 \mathrm{mln}$ euro. Podobne misje obserwatorów skierowano do Libanu w 2005 r. i Iraku w 2004 r. Unia Europejska za pośrednictwem EIDHR ogłaszała konkursy skierowane do europejskich organizacji pozarządowych w celu nawiązania kontaktu i wspierania organizacji pozarządowych w państwach regionu. Na realizację takich zadań UE przekazała środki finansowe w wysokości od 100 tys. do 300 tys. euro na jeden projekt (EIDHR, 2006). Warto również podkreślić, iż w ramach EIDHR Unia Europejska wspiera program o charakterze edukacyjnym. Przykładem jest forum regionalne utworzone na Uniwersytecie na Malcie i finansowane przez UE. W ramach The Mediterranean Master of Arts in Human Rights and Democratization na studiach podyplomowych dokształcali się pracownicy wymiaru sprawiedliwości, więziennictwa, aktywiści organizacji pozarządowych, działacze społeczni, prawnicy, dziennikarze i liderzy społeczności lokalnych pochodzący z państw partnerskich.

Kolejnym programem autorstwa Unii Europejskiej, którego jednym z celów było wspieranie procesów demokratyzacyjnych w państwach Afryki Północnej i Bliskiego Wschodu był proces barceloński zwany także Partnerstwem Eurośródziemnomorskim. Pierwowzorem polityki UE w ramach Partnerstwa Eurośródziemnomorskiego były Global Mediterranean Policy z 1972 roku oraz New Mediterranean Policy z 1990 roku. Pomysłodawcą tego projektu była Hiszpania, kierująca pracami Komisji Europejskiej. Spotkanie zorganizowano w Barcelonie w listopadzie 1995 roku, na które przybyli przedstawiciele 15 państw Unii Europejskiej i 12 państw z Afryki Północnej i Bliskiego Wschodu. W gronie państw spoza Unii Europejskiej uczestniczących w szczycie politycznym w Barcelonie znalazły się: Algieria, Cypr, Egipt, Izrael, Jordania, Liban, Malta, Maroko, Palestyna, Syria, Tunezja i Turcja (Bezpieczeństwo...). Turcja miała specjalny status z uwagi na toczące się rozmowy akcesyjne z Unią Europejską. Chociaż Jemen nie był uczestnikiem Partnerstwa to z powodu podpisania umowy o współpracy UE z Jemenem w 1990 roku nieformalnie korzystał z pomocy finansowej. Podczas konferencji barcelońskiej państwa europejskie nakłoniły do podjęcia próby współpracy między wrogami: Izraelem i państwami arabskimi, takimi jak Autonomia Palestyńska, Syria, Jordania i Liban (Euro-Mediterranean...). Spotkanie w Barcelonie ma znaczenie przełomowe dla współpracy w regionie, gdyż Unia Europejska zainicjowała kompleksową i całościową politykę wobec państw tego regionu. Po raz pierwszy w historii politycy europejscy zdecydowali się realizować politykę śródziemnomorską bez podziału na regiony. Głównym celem, podpisanego na szczycie w Hiszpanii porozumienia było zacieśnienie współpracy w wymiarze ekonomicznym oraz politycznym, w efekcie którego miała zostać utworzona do 2010 r. eurośródziemnomorska strefa ekonomiczna i polityczna. Jedne z istotnych elementów współpracy politycznej stanowiły postulaty demokratyzujące życie polityczne w państwach śródziemnomorskich. Współpraca eurośródziemnomorska w zakresie reform politycznych miała przebiegać na poziomie multilateralnym (UE - partnerskie państwa śródziemnomorskie) i bilateralnym (umowy zawierane pomiędzy konkretnymi 
państwami, poza strukturami UE). Realizacja Deklaracji Barcelońskiej miała się odbywać w oparciu o trzy koszyki:

- partnerstwo polityczne i w sferze bezpieczeństwa,

- partnerstwo ekonomiczne i finansowe,

- partnerstwa w dziedzinie kulturalnej, społecznej i humanitarnej ${ }^{1}$.

W realizacji pierwszego koszyka miała służyć Eurośródziemnomorska Karta Pokoju i Stabilizacji (The Euro-Mediterranean Charter for Peace and Stability). Niestety rozbieżności między uczestnikami konferencji barcelońskiej były zbyt duże, zwłaszcza między państwami arabskimi a Izraelem i dokument końcowy nie został przyjęty. Do podpisania Karty potrzebna była zgoda wszystkich 27 krajów. Jednym z obszarów niezgody była próba wprowadzenia zapisu dotyczącego pośrednictwa Unii Europejskiej w rozwiązywaniu konfliktów, czemu solidarnie sprzeciwili się politycy państw arabskich. Pomimo tego, iż Karta nie została przyjęta należy odnotować postęp w pracach między państwami śródziemnomorskimi nad bezpieczeństwem i stabilizacją w regionie. Zainaugurowała działalność EuroMeSCo czyli Euro-Śródziemnomorska Komisja Badań (Euro-Mediterranean Study Commission), którą tworzy sieć 34 instytutów naukowych. W latach 2001-2002 EuroMeSCo realizowała programy badawcze w zakresie: dialogu politycznego, wspólnej polityki zagranicznej partnerów śródziemnomorskich oraz przedsięwzięć o charakterze subregionalnym. W ramach EuroMeSCo zorganizowano cykl wykładów dla dyplomatów i utworzono The Mediterranean Academy of Diplomatic Studies. Uczestnicy studiów zapoznawali się z działalnością Unii Europejskiej, jej strukturami i procesem podejmowania decyzji. Program wymiany studenckiej Tempus został rozszerzony o państwa śródziemnomorskie. Decydenci UE oczekiwali, iż dzięki współpracy między uczelniami państw Procesu Barcelońskiego nastapi modernizacja systemu szkolnictwa wyższego w państwach regionu. W 2003 roku powstała kolejna forma współpracy skierowana do młodzieży The Euro-Mediterranean Youth Platform (EuroMed).

Na szczególną uwagę zasługuje fakt włączenia do aktywnej współpracy euro-śródziemnomorskiej Libii. Pułkownik Muommar Kadafi w 2004 r. po zmianie polityki zagranicznej podjął starania, mające na celu włączenie Libii do procesu barcelońskiego. Widząc korzyści wynikające z powrotu Libii do międzynarodowej społeczności, libijski przywódca wziął na siebie odpowiedzialność za zamachy w Lockerbie w 1988 r. i zrezygnował z kosztownego programu budowy broni jądrowej. Ważnym krokiem na drodze do zmiany pozycji Libii ze statusu obserwatora w ramach procesu barcelońskiego i włączenia tego kraju w poczet członków tej inicjatywy było spotkanie Kadafiego z przewodniczącym Komisji Europejskiej Romano Prodim 28 lutego 2004 r., które odbyło się w libijskim mieście Sirte. Prodi w imieniu Komisji Europejskiej zapewnił władze libijskie, iż w najbliższej przyszłości skontaktuje się z Europejskim Bankiem Inwestycyjnym w celu podjęcia wspólnej inicjatywy, która doprowadzi do przystąpienia Libii do procesu barcelońskiego jako pełnoprawnego członka (Libia..., 2004).

Unia Europesjska zdecydowała o powałaniu do życia Mediterranean Economic Development Assistance instrumentu finansowego, na podstawie którego miały być realizowane

${ }^{1}$ Ciekawą analizę polityki Unii Europejskiej wobec regionu Morza Śródziemnego i Partnerstwa Eurośródziemnomorskiego przeprowadziła Justyna Zając w swoich pracach: Partnerstwo Eurośródziemnomorskie, Warszawa 2005 oraz Polityka Unii Europejskiej w regionie śródziemnomorskim, Toruń 2002 (szerzej zobacz w: Zając, 2002, s. 111-117). 
zadania w ramach Partnerstwa Eurośródziemnomorskiego. Na lata 1995-1999 zaplanowano program MEDA I, w ramach którego Unia Europejska przekazała państwom północnoafrykańskim środki finansowe w wysokości 3,4 mld euro. Dodatkowo Europejski Bank Inwestycyjny oddał do dyspozycji partnerów afrykańskich 4,8 mld euro. Niestety $\mathrm{z}$ różnych powodów wykorzystano tylko $26 \%$ środków, tj. $890 \mathrm{mln}$ euro (The MEDA System). Unia Europejska jest jednak zdeterminowana w swych działaniach i w latach 2000-2006 realizowany był program MEDA II. Budżet tego programu określono na 5,3 mld euro. Część pomocy kierowana jest do poszczególnych państw, część na realizację projektów regionalnych (The MEDA System). W 2007 roku program MEDA został zastapiony Europejskim Instrumentem Sąsiedztwa i Partnerstwa. Budżet nowej inicjatywy opiewał na kwotę 12 mld euro, a okres realizacji określono na lata 2007-2012. Znaczący wzrost środków finansowych od 2007 roku spowodowany był połączeniem budżetów Partnerstwa Eurośródziemnomorskiego i Europejskiej Polityki Sąsiedztwa (European Commission, 2007).

Partnerstwo Eurośródziemnomorskie stanowiło integralną część polityki zagranicznej Unii Europejskiej z państwami trzecimi. Realizację programu należy rozpatrywać dwuwymiarowo. Wymiar bilateralny polegał na zawieraniu porozumień pomiędzy stronami, które miały charakter prawnie obowiązujący. Aspekt multilateralny polegał na organizacji wspólnych śródziemnomorskich międzynarodowych konferencji, które nie powodowały konsekwencji legislacyjnych. W przeciwieństwie do EIDHR zadania demokratyzacyjne stanowiły jedynie część spośród celów określonych w Deklaracji Barcelońskiej w 1995 roku. Reformy demokratyzacyjne w ramach Partnerstwa Eurośródziemnomorskiego miały być prowadzone na zasadzie podejścia odgórnego (a top - down approach). Działania te wspierały rządy państw partnerskich, które wykazywały otwartość i chęć uczestnictwa w procesach demokratyzacyjnych życia politycznego danego państwa. Demokratyzacja według zapisów Partnerstwa polegała na wspieraniu modernizacji struktur policji, reformowaniu wymiaru sprawiedliwości, administracji państwowej oraz promowaniu zasady transparentności wyborów władz każdego szczebla. Przykładowo w latach 2005-2006 w ramach National Indicative Programme przeprowadzono reformę marokańskiego wymiaru sprawiedliwości. Strona europejska sfinansowała zakup komputerów, baz danych oraz koszty szkoleń urzędników ministerstwa. Celem było usprawnienie działania sądów marokańskich oraz wprowadzenie zasady transparentności w ich funkcjonowaniu (European Commission, 2005).

W latach 2000-2004 największymi beneficjentami udzielonej przez UE pomocy w ramach Partnerstwa Eurośródziemnomorskiego okazały się: Maroko (430 mln euro), Egipt (370 mln euro), Autonomia Palestyńska (320 mln euro), Tunezja (310 mln euro) i Jordania (250 mln euro) (European Commission, 2004).

W celu osiagnięcia w maksymalnym stopniu przyjętych pierwotnie zadań Partnerstwo Eurośródziemnomorskie zostało oparte o instytucjonalne formy współpracy regionalnej. W latach 1995-2006 na poziomie eurośródziemnomorskiej współpracy rządowej odbyło się siedem konferencji konsultacyjnych ministrów spraw zagranicznych, na których poruszano kwestie realizacji zadań o charakterze demokratyzacyjnym i z zakresu praw człowieka. Problemy te znalazły się w koszyku pierwszym - polityka i bezpieczeństwo. Raz na kwartał odbywały się spotkania w ramach Eurośródziemnomorskiej Komisji, do której zadań należało przygotowanie tematów dyskusyjnych na szczyty mini- 
sterialne ministrów spraw zagranicznych państw eurośródziemnomorskich. Na szczeblu parlamentarnym w 2004 roku powstało Eurośródziemnomorskie Zgromadzenie Parlamentarne (The Euro-Mediterranean Parliamentary Assembly), w którego skład weszło 240 członków, połowa z państw UE połowa z państw śródziemnomorskich. Ciało to tworzyły cztery komisje tematyczne: Komisja ds. polityki, bezpieczeństwa i praw człowieka, Komisja ds. ekonomii, polityki społecznej oraz edukacji, Komisja ds. poprawy jakości życia i kultury oraz Komisja ds. praw kobiet. Spotkania robocze wyznaczono na marzec każdego roku, w różnych miastach. Utworzono także the Euro-Mediterranean Civil Forum, którego zadaniem było wzmocnienie Procesu Barcelońskiego ideą budowy społeczeństwa obywatelskiego. Uczestnikami tego ciała byli przedstawiciele wszystkich państw regionu eurośródziemnomorskiego. Forum zwołano dziesięć razy pomiędzy 1996 a 2006 rokiem. Podczas obrad wypracowywano rozwiązania dla decydentów w następujących zakresach tematycznych: prawa człowieka, równouprawnienie kobiet, transparentność wyborów, organizacja związków zawodowych, edukacja i kultura. W 2004 roku powołano do życia Eurośródzimnomorską Fundację Anny Lindh na rzecz Dialogu pomiędzy Kulturami w celu promowania współpracy między społeczeństwami państw członkowskich Procesu Barcelońskiego (Gillespie, Youngs, 2002, s. 68).

Pozytywne doświadczenia w ramach Partnerstwa Eurośródziemnomorskiego, którego początki sięgają 1995 r. zaowocowały stworzeniem 12 maja 2004 r. Europejskiej Polityki Sąsiedztwa (EPS). Prace wstępne nad nową koncepcją stosunków z państwami trzecimi zapoczątkowano 18 listopada 2002 r., kiedy Rada Europy podjęła decyzję o powołaniu Inicjatywy dla Nowego Sąsiedztwa. Po akceptacji przez Komisję Europejską EPS stała się częścią polityki zagranicznej prowadzonej przez Unię Europejską. Pomysłodawcami EPS było kilku głównych polityków, przedstawicieli zarówno Komisji Europejskiej, jak i poszczególnych państw europejskich. Jako najważniejszych z nich należy wymienić: ówczesnego przewodniczącego Komisji Europejskiej Romano Prodiego, ministra spraw zagranicznych Wielkiej Brytanii Jacka Strowa oraz minister spraw zagranicznych Szwecji Annę Lindh. EPS obejmuje trzy regiony: Azji Centralnej, obszar za wschodnią granicą Unii oraz obszar, z którym współpraca stała się podstawą do stworzenia EPS, czyli region śródziemnomorski (Serwis o Unii Europejskiej...).

Warto zaznaczyć, iż EPS skierowana jest również do specyficznego i trudnego partnera, jakim jest Rosja. EPS jest skierowana do państw, które są najbliższymi sąsiadami Unii. Głównym celem jest utworzenie wokół UE kręgu państw przyjaznych, funkcjonujących na podstawie podobnych zasad. Benita Ferrer-Waldner, komisarz ds. stosunków zewnętrznych i europejskiej polityki sąsiedztwa wówczas oświadczyła: „Moim celem jest stworzenie kręgu przyjaciół wokół granic rozszerzonej UE. [...] Pracowaliśmy z naszymi sąsiadami, aby wytyczyć odpowiednie dla każdego z nich plany, które spełnią potrzeby i odzwierciedlą ich prośby. Nasza oferta - zwiększona współpraca, większa pomoc finansowa, a także szansa skorzystania z bliższych stosunków z Europą - przyniesie rzeczywiste korzyści obu stronom w wielu obszarach, od edukacji po środowisko naturalne i od transportu po zwalczanie terroryzmu" (Serwis informacyjny..., 2004).

Współpraca w ramach EPS dotyczy trzech zasadniczych kwestii:

1) propagowanie działań, mających na celu poszanowanie praw człowieka, demokracji i rządów prawa, poprzez uczestnictwo sygnatariuszy we Wspólnej Polityce Zagranicznej i Bezpieczeństwa UE oraz Europejskiej Polityce Bezpieczeństwa i Obrony; 
2) współpraca gospodarcza, której celem jest wzrost poziomu życia w krajach sąsiedzkich i dopuszczenie ich mieszkańców do rynku wewnętrznego UE;

3) kooperacja w ramach Obszaru Sprawiedliwości i Spraw Wewnętrznych, np. wspólne działania o charakterze edukacyjnym czy w zakresie efektywnej ochrony granic (Serwis o Unii Europejskiej...).

Podobnie jak w przypadku Partnerstwa Eurośródziemnomorskiego tu też mamy do czynienia z elementami demokratyzacji. Przykładowo w latach 2004-2006 na podstawie bilateralnych umów tzw. Action Plans w ramach programu Justice Project UE przekazała kilku państwom środki w wysokości 155,2 mln euro. Podstawowe zadania projektu sprowadzały się do: dokształcania urzędników i sędziów, modernizacji systemu sprawiedliwości, aby podnieść jakość usług i przestrzegania praw człowieka w postępowaniach sądowych. Inny projekt to Police Project, którego celem było szkolenie sił policyjnych i przestrzeganie praw człowieka przez policjantów, zgodnie z obowiązującymi międzynarodowymi standardami.

\section{Stany Zjednoczone}

Bill Clinton jako pierwszy prezydent Stanów Zjednoczonych położył szczególny nacisk na promocję haseł demokratycznych w różnych regionach świata. Koncepcja potrzeby wspierania demokracji zajmuje w polityce prezydenta Clintona centralne miejsce (szerzej zobacz w: A National..., 1995). W swojej koncepcji Clinton nawiązywał do działań demokratyzacyjnych prezydenta Woodrow Wilsona z początku XX wieku. Prezydent George W. Bush w tym sektorze polityki kontynuował linię przyjętą przez poprzednika. Prezentowane poniżej programy demokratyzacyjne, skierowane do państw Afryki Północnej i Bliskiego Wschodu były realizowane przez administrację prezydenta George'a W. Busha, powszechnie kojarzonej z wykorzystaniem narzędzi z zakresu arsenału środków hard power. Rzeczywiście, interwencje zbrojne przeprowadzone przez Stany Zjednoczone po zakończeniu zimnej wojny skupiają się w głównej mierze na obszarze Afryki i Bliskiego Wschodu (Kłosowicz, 2008, s. 276). Jednak poza współpracą militarno-polityczną ważne miejsce w stosunkach USA z państwami regionu w okresie sprawowania urzędu prezydenta przez George'a W. Busha zajmowały następujące inicjatywy promujące wartości demokratyczne: Human Rights and Democracy Fund (HRDF), United States Agency for International Development (USAID), Middle East Partnership Initiative (MEPI), The Greater Middle East Initiative (GMEI) oraz Broader Middle East and North Africa Initiative (BMENAI).

Pierwszą inicjatywą urzędników Biura ds. Demokracji, Praw Człowieka i Pracy Departamentu Stanu USA była Human Rights and Democracy Fund (HRDF), której początki sięgają 1998 roku. Program dotyczył różnych części świata, ale najwięcej uwagi Stany Zjednoczone poświęcały rejonowi Afryki Północnej i Bliskiego Wschodu. Przykładowo w 2010 roku aż 48\% (200 mln USD) budżetu agencji przekazano na działania demokratyzacyjne w Iraku, przy jedynie 6\% (24 mln USD) wsparciu projektów w Europie Wschodniej. W Iraku finansowanych jest aż 50 programów demokratyzacyjnych, a w pozostałych państwach regionu 22 programy z kwotą przekraczającą $32 \mathrm{mln}$ USD (U.S. Department of State, Supporting Human Rights and Democracy: The U.S. Record). 
Do kluczowych zadań powołanego funduszu zaliczono: szerzenie haseł tolerancji religijnej w arabskich krajach Bliskiego Wschodu i Afryki Północnej, wspieranie walki o prawa kobiet, zachęcanie do reform systemu prawnego oraz wspieranie tworzenia wolnych i pluralistycznych mediów. Stany Zjednoczone przywiązywały szczególną wagę do wspierania wolności i tolerancji religijnej. Według raportu z 2008 roku, jednym z głównych zadań było wspieranie mniejszości religijnych w państwach regionu oraz zachęcanie władz do przestrzegania zasady wolności praktyk religijnych. Dane z 2008 roku potwierdzały zasadność działań podjętych przez urzędników Departamentu Stanu. Państwa regionu znajdowały się w czołówce rankingu państw, wśród których wolność religijna jest zagrożona w stopniu najwyższym (U.S. Department of State, 2008). Prezydent Bush docenił rolę jaką spełniała HRDF w procesie demokratyzacji krajów arabskich i zwiększył budżet organizacji aż czterokrotnie z 13 mln 421 tys. USD w 2001 r. do $48 \mathrm{mln}$ 112 tys. USD w 2005 r. (U.S. Department of State, 2005). Natomiast całkowity budżet inicjatywy wzrastał lawinowo z $7 \mathrm{mln}$ w 1998 roku do ponad $207 \mathrm{mln}$ USD w 2010 roku. W rekordowym 2007 roku HRDF dysponowała kwotą 310 mln USD (U.S. Department of State, Bureau...). Podstawowa cecha charakterystyczna wyróżniająca HRDF spośród innych programów polega na tym, iż większość projektów w jej ramach skierowano do organizacji pozarządowych, liderów lokalnych ruchów politycznych i władz lokalnych w celu budowy społeczeństwa obywatelskiego i decentralizacji struktur państwowych. Pozytywnym przykładem jest rozpoczęcie, dzięki działaniom HRDF procesu decentralizacji w Egipcie (U.S. Department of State, 2009). Ponadto, HRDF to inicjatywa skupiająca się jedynie na realizacji zadań z zakresu wspierania procesów demokratyzacyjnych. Brak w jej programie działania zadań np. wspierających rozwój ekonomiczny poszczególnych państw. Zasadniczy element różniący HRDF od programów Unii Europejskiej polegał na dopuszczeniu do jego finansowania partii politycznych i organizacji partyjnych. Zasada ta jest stosowana w przypadku agencji The National Endowment for Democracy (NED) wspierającej HRDF. Fundusze przekazywane przez NED pochodzą z amerykańskich instytucji partyjnych: The International Republican Institute (IRI) oraz National Democratic Insitute for International Affairs (NDI). Sztandarowe projekty NED-IRI-NDI dotyczyły wspierania budowy struktur partyjnych w Iraku. Tylko na ten cel w 2004 roku wyasygnowano sumę $11 \mathrm{mln}$ USD. Strona amerykańska sfinansowała zakup komputerów wraz z oprogramowaniem i organizację wyborów parlamentarnych w Iraku. Agencja NED współpracowała ściśle z ambasadami USA w państwach regionu, aby rozpoznać rzeczywiste potrzeby beneficjentów. Warto podkreślić, iż w porównaniu do innych programów działalność HRDF nie jest ograniczona względami formalnymi, a biurokracja ograniczona jest do minimum (NED, Description of 2004...).

Kolejną inicjatywą była Middle East Partnership Initiative (MEPI). Pomysł jej powstania zrodził się w Biurze ds. Demokracji, Praw Człowieka i Pracy Departamentu Stanu USA bezpośrednio po atakach terrorystycznych z 11 września 2001 r. Po ponad rocznych przygotowaniach, w grudniu 2002 roku, korzystając z doświadczeń HRDF, administracja Georga W. Busha podjęła decyzję o powołaniu do życia rozbudowanej tematycznie względem HRDF Middle East Partnership Initiative. Należy zaznaczyć, iż poza zadaniami mającymi na celu wspieranie przemian demokratycznych Stany Zjednoczone umieściły wśród priorytetów MEPI także działania o charakterze gospodarczym. Program jest nadzorowany przez urzędników Bureau of Near Eastren Affair's Office of 
Assistane Coordination. MEPI stała się pierwszym programem na rzecz wspierania procesów demokratyzacyjnych w krajach arabskich Afryki Północnej i Bliskiego Wschodu ogłoszonym podczas prezydentury Georga W. Busha. Realizacja MEPI dotyczyła: reform ekonomicznych, inwestycji gospodarczych, rozwoju sektora prywatnego, edukacji, wspierania pluralizmu politycznego i budowy wolnych mediów, reformy systemu sprawiedliwości, zachęcania państw regionu do tworzenia różnych form współpracy i budowy społeczeństwa obywatelskiego. MEPI nie jest częścią żadnej zinstytucjonalizowanej formy współpracy zarówno na poziomie międzyrządowym, jak i lokalnym. Wyjątkiem jest US - Middle East University Partnership (Huber, 2008, s. 51).

Główne zadania MEPI zostały zdefiniowane na podstawie ogłoszonego przez ONZ Arab Human Development Report opublikowanego w 2003 roku. W latach 2002-2003 ONZ przeprowadziła badania, których wyniki opublikowane w UN Arab Human Development Report (UNAHDR) obrazowały dramatyczny stan społeczeństw państw arabskich. Za trzy najważniejsze problemy - bariery w rozwoju demokracji uznano: brak wolności, brak wykształcenia i wiedzy oraz pozbawienie kobiet jakichkolwiek praw. Ponad $40 \%$ dorosłych Arabów, w tym 2/3 to kobiety, to analfabeci, zaledwie $2 \%$ miało dostęp do Internetu, a jedynie 3,5\% miejsc w tamtejszych parlamentach zajmowały kobiety (nawet w państwach Afryki subsaharyjskiej odsetek kobiet w parlamentach wynosił 8,4\%) (Girdner, s. 45). Zdaniem ONZ państwa arabskie rejonu Afryki Północnej i Bliskiego Wschodu prezentowały najniższy stopień wolności obywatelskich. Powyższe problemy powodują niepokojące konsekwencje i tworzą realne zagrożenia dla bezpieczeństwa międzynarodowego. Wielu członków społeczeństw arabskich jest podatnych na propagandę grup fundamentalistów oraz działań terrorystów. Równie niepokojący jest wzrost liczby nielegalnych imigrantów, najczęściej ludzi młodych, którzy w poszukiwaniu lepszych perspektyw życiowych podejmują ryzyko i decydują się na wyjazd do Europy lub USA. Według danych z raportu aż 51\% młodych Arabów zadeklarowało wolę wyjazdu (Gambill, 2004, s. 32).

Fundamenty społeczeństwa obywatelskiego tj. edukacja, a w przypadku państw arabskich edukacja kobiet oraz wolność słowa stały się priorytetami dla MEPI od początku jej istnienia. Koordynacją realizacji zadań programu zajmowały się terenowe biura utworzone w Tunisie oraz Abu Dabi. Warto odnotować fakt, iż ich działalność była wspierana nie tylko przez arabskie i międzynarodowe organizacje pozarządowe, stowarzyszenia akademickie, ale również przez władze lokalne. Pomiędzy 2002 a 2009 rokiem Kongres USA przeznaczył na program MEPI $530 \mathrm{mln}$ USD, dzięki którym sfinansowano ponad 600 projektów obywatelskich w 17 arabskich krajach Bliskiego Wschodu i Afryki Północnej. Poza Marokiem najwięcej zyskały organizacje działające w: Jemenie, Bahrajnie, Tunezji i Algierii, najmniej w Arabii Saudyjskiej i Egipcie (Carothers, 2005). Wzrost nakładów finansowych na MEPI to niewątpliwy sukces pomysłodawców programu. Przykładowo budżet wzrósł z 29 mln USD w 2002 roku do 75 mln USD w 2005 roku. Za sukces MEPI można również uznać przystapienie do projektu w 2005 roku Libii. Od 2002 roku do 2015 roku w ramach MEPI zrealizowano ogółem 1000 projektów na sumę 900 mln USD (U.S. Department of State, Middle East Partnership Initiative).

Według administracji prezydenta Busha, aby program przyniósł maksymalne korzyści jego realizacja odbywała się na dwóch płaszczyznach: lokalnej i regionalnej, polegającej na wspieraniu współpracy pomiędzy państwami regionu za pomocą odpowiednich 
szczegółowych projektów. Na płaszczyźnie lokalnej działa tzw. Local Grant Program, za funkcjonowanie którego odpowiedzialni są pracownicy ambasad USA w poszczególnych państwach regionu. Diagnozowane są najważniejsze problemy społeczno-polityczne w danym państwie np. budowa społeczeństwa obywatelskiego, wspieranie niezależnych mediów, walka o prawa kobiet, tolerancja religijna. Następnie koordynatorzy MEPI w każdej z ambasad USA dokonują kwalifikacji problemów i kierują projekty (key projects) wraz z odpowiednim wsparciem finansowym adresowane do organizacji pozarządowych, liderów tych stowarzyszeń lub władz lokalnych. Granty przyznawane są w wysokości od 25 tys. do 100 tys. USD, a ich okres realizacji trwa jeden rok. Od początku istnienia MEPI z tego rodzaju współpracy skorzystało 250 podmiotów. Współpracą na szczeblu regionalnym kieruje biuro centralne MEPI w Waszyngtonie, które wspiera projekty dotyczące kilku państw regionu. Technicznie współpraca polega na wymianie doświadczeń i kadr pomiędzy państwami i wspólnej nauce. Jeden z grantów zachęcał do kooperacji przedstawicielki świata prawniczego z Maroka i Kuwejtu. Podobnie jak w przypadku programu HRDF, z ambasadami USA współpracowała agencja NED (Gershman, 2003).

W zakresie reform politycznych zorganizowano szereg konferencji na temat demokratycznych praktyk, systemów partyjnych, wolnych wyborów, wolnych mediów czy wymiaru sprawiedliwości. Przykładowo w Maroku programem administruje The International Republican Institute, który tylko w jednym roku swojej działalności przeznaczył na zorganizowanie konferencji międzynarodowych $1 \mathrm{mln} 250$ tys. USD. Z kolei podczas wyborów parlamentarnych w Libanie w 2005 roku w ramach MEPI sfinansowano pobyt obserwatorów międzynarodowych, opłacono program edukacji wyborczej. Podobne korzyści z MEPI odnieśli Egipcjanie podczas wyborów prezydenckich, które odbyły się we wrześniu 2005 roku. Jeszcze w marcu 2005 r. MEPI przekazała $1 \mathrm{mln}$ USD wsparcia dla egipskich organizacji pozarządowych w celu promocji idei wolnych wyborów. Warto zaznaczyć, iż były to pierwsze wybory na urząd prezydenta kraju, w których partie opozycyjne mogły zaprezentować swoich kandydatów. Stany Zjednoczone skierowały również do dziennikarzy egipskich 14-miesięczny program grantowy, przygotowujący do bezstronnej pracy informacyjnej podczas wyborów parlamentarnych (U.S. Department of State, Middle East Partnership Initiative. Success Stories). Ważnym krokiem w reformowaniu systemu sprawiedliwości świata arabskiego przez MEPI było zorganizowane w Bahrajnie w 2003 roku the Arab Judicial Forum. W trzydniowym wydarzeniu wzięli udział przedstawiciele 15 państw arabskich oraz Wielkiej Brytanii i Stanów Zjednoczonych. Na czele delegacji prawników USA stanęła sędzia Sądu Najwyższego USA Sandra Day O’Connor. Forum prawnicze dotyczyło czterech kwestii tematycznych: system sądowniczy a prawa człowieka, zasada niezawisłości sędziów od władz politycznych, walka z korupcją, podniesienie jakości i sprawności systemu sprawiedliwości oraz regionalna współpraca struktur wymiaru sprawiedliwości w ściganiu przestępców (U.S. Department of State, Supporting Human Rights and Democracy: The U.S. Record 2003-2004).

Do marca 2010 roku dzięki wsparciu programu MEPI przeszkolono 400 aktywistek i kandydatek na parlamentarzystów przed wyborami parlamentarnymi w Iraku. Powołano do życia National Platform for Women, w skład której weszło 200 kobiet i mężczyzn reprezentujących irackie partie polityczne, różne organizacje społeczne i świat mediów. 
Naczelnym zadaniem było wzmocnienie pozycji kobiet w życiu politycznym Iraku. Była to odpowiedź na wyniki United Nations Arab Human Development Report opublikowanego w 2003 roku. Raport wykazał, iż jednym z najpoważniejszych problemów społeczeństw arabskich jest dyskryminacja kobiet. Z kolei do Libanu skierowano program promujący tolerancję religijną (U.S. Department of State, DRL Programs...).

United States Agency for International Development (USAID) to następny program Stanów Zjednoczonych, którego jednym z zadań jest promowanie haseł demokratyzacyjnych. Od ponad 40 lat, USAID kieruje swoje programy, do społeczeństw i rządów arabskich państw regionu w celu krzewienia „pokoju i stabilności poprzez wspieranie rozwoju gospodarczego, ochronę zdrowia, organizowanie pomocy humanitarnej oraz zachęcanie do zmian demokratycznych w państwach rozwijających się"2. Od przełomu lat 60. i 70. XX wieku adresatami programów autorstwa USAID były państwa arabskie Bliskiego Wschodu, natomiast w latach 80 . XX wieku objęto nią również mieszkańców Maghrebu. W 1994 roku decyzją prezydenta Billa Clintona utworzono w ramach USAID The Democracy and Governance Unit (DGU), której zadaniem jest realizacja programów demokratyzacyjnych. Wydatki tej agencji stanowiły pod koniec lat 90 . XX wieku 5,8\% całości budżetu USAID i wykazują tendencję rosnącą. W 1990 roku USAID zrealizowała projekty demokratyzacyjne w państwach Bliskiego Wschodu i Afryki Północnej za łączną kwotę $1 \mathrm{mln} 940$ tys. USD. W 2003 roku wydatki agencji osiagnę̨y sumę 189 mln USD (Finkel, Perez-Linan, Seligson, 2006, s. 31). Hasłem priorytetowym stało się promowanie rozwiązań demokratycznych w państwach arabskich i zachęcanie społeczeństw tych państw do podjęcia prób budowy obywatelskich struktur administracyjnych. W przeciwieństwie do programu MEPI działania USAID w zakresie demokratyzacji państw regionu charakteryzuje zrównoważenie programów wspierających budowę społeczeństwa obywatelskiego i organizacji pozarządowych z nakładami na reformę instytucji władz centralnych. Pomiędzy 1990 a 2003 rokiem 51\% funduszy trafiało do organizacji pozarządowych i władz lokalnych, $40 \%$ na reformę instytucji rządowych, a 9\% na rozwój partii politycznych oraz organizację i kontrolę wyborów parlamentarnych (Finkel, Perez-Linan, Seligson, 2006, s. 36). Proporcje te uległy zmianie podczas wojny w Iraku. W latach 2004-2006 58\% środków przekazano na reformę urzędów administracji rządowej, $27 \%$ to wydatki na wsparcie dla władz lokalnych i organizacji pozarząadowych, a 15\% budżetu USAID przekazała na organizację wyborów i rozwój struktur partii politycznych (USAID, 2006a).

W latach 2001-2005 roku największymi beneficjentami programu były następujące kraje: z Afryki Maroko i Egipt, z Bliskiego Wschodu Jemen, Jordania, Liban oraz Autonomia Palestyńska. Jednak największym beneficjentem był Irak. Wydatki USAID na przemiany demokratyczne w Iraku wyniosły 15 USD w przeliczeniu na jednego mieszkańca, w Jordanii 6 USD, a w Autonomii Palestyńskej 4 USD (Huber, 2008, s. 51). Od 2009 roku po objęciu urzędu prezydenta przez Baracka Obamę, sekretarz stanu Hillary Clinton określiła priorytetowe cele działalności amerykańskich programów pomocowych kierowanych do świata arabskiego. Na pierwszym miejscu administracja Obamy postawiła cele związane z rozwojem gospodarczym i tworzeniem nowych miejsc pracy,

${ }^{2},[\ldots]$ peace and stability by fostering economic growth, protecting human health, providing emergency humanitarian assistance, and enhancing democracy in developing countries" (podaję za: USAID, 2006b). 
natomiast procesy demokratyzacyjne mają nastąpić w konsekwencji podniesienia stopy życiowej i poprawy warunków życia w państwach regionu (zobacz w: Hassan, 2013, s. 157-180). Implementacją założeń zajęła się istniejąca od dwudziestu pięciu lat Center for International Private Enterprise (CIPE), będąca jednym z czterech współprogramów w ramach National Endowment for Democracy (NED) (więcej w: Scott, Steele, 2005). CIPE jest organizacją nonprofit i działa przy US Chamber of Commerce. Ponadto USAID roztacza swoistego rodzaju instytucjonalny parasol ochronny nad działaniami innych organizacji np. MEPI w państwach, które są beneficjentami programów (Clinton, 2010).

Spośród przykładowych projektów demokratyzacyjnych zrealizowanych przez USIAD w państwach Afryki Północnej i Bliskiego Wschodu warto wymienić wsparcie dla reformy ustrojowej za pomocą metod parlamentarnych poprzez wybory oraz dla tworzenia samorządu lokalnego w Maroku. W 2005 roku USAID zainwestowała w rozwój instytucji demokracji lokalnej $5 \mathrm{mln}$ USD. Środki finansowe pokryły koszty organizacji konferencji, warsztatów lub szkolenia urzędników dotyczące np. planowania budżetów lokalnych (USAID, 2004). Ważną częścią pomocy udzielonej Maroku było dofinansowanie edukacji, począwszy od szkół podstawowych przez średni szczebel, kończąc na szkolnictwie wyższym. Tylko na ten cel w 2005 roku Amerykanie przekazali za pośrednictwem USAID ponad 6 mln USD. Znaczna czesść tej kwoty pokryła koszty dokształcenia kadry pedagogicznej (U.S. Department of State, 2006). W 2005 roku USAID sfinansowała reformę wymiaru sprawiedliwości na terytorium Autonomii Palestyńskiej, rok później kwotą 59 mln USD wsparto organizację wyborów parlamentarnych i stworzenie prowincjonalnych ciał ustawodawczych w Iraku, w tym w Kurdystanie. Do Egiptu USAID skierowała projekty związane z rozwojem pluralistycznego rynku mediów, również na szczeblu lokalnym. W Libanie realizowano projekty promujące tolerancję religijną między wyznawcami różnych religii (Sharp, 2006).

Na koniec należy wspomnieć o dwóch programach, których priorytetami były zadania z zakresu gospodarki i bezpieczeństwa, ale istniały w nich również elementy dotyczące przemian demokratycznych. Chodzi o The Greater Middle East Initiative (GMEI) oraz Broader Middle East and North Africa Initiative (BMENAI). Decyzją prezydenta Busha z listopada 2003 roku z budżetu NED wyasygnowano sumę $40 \mathrm{mln}$ USD na rzecz utworzenia GMEI, nowej instytucji współpracy między USA a arabskimi krajami Afryki Północnej i Bliskiego Wschodu oraz Izraelem i Turcją. Integralną częścią programu o charakterze gospodarczym było wyrażenie zgody tamtejszych władz na rozpoczęcie procesu demokratyzacji życia politycznego w państwach regionu. Spośród zadań politycznych GMEI wymienić należy: promowanie współpracy politycznej i gospodarczej pomiędzy państwami Afryki Północnej i Bliskiego Wschodu, utworzenie Greater Middle East Democracy Assistance Group w celu promocji politycznych rozwiązań demokratycznych wśród społeczeństw państw członkowskich oraz powołanie do życia Greater Middle East Literacy Corps (Neep, 2004, s. 62).

Efekty działań Stanów Zjednoczonych w aspekcie szerzenia rozwiązań demokratycznych były widoczne bardzo szybko. Już w 2005 roku prezydent Hosni Mubarak, dyktator Egiptu zezwolił na powstanie Narodowego Zgromadzenia ds. Praw Człowieka. W Libii pułkownik Muommar Kaddafi podjął decyzję o liberalizacji prawa; zniesiono specjalne ustawy, które wykorzystywano do walki politycznej. Z kolei władze Autonomii 
Palestyńskiej zobowiązały się do przeprowadzenia wolnych wyborów parlamentarnych. Król Arabii Saudyjskiej zaproponował powołanie Forum Narodowego Dialogu, w ramach którego mają zostać przygotowane wybory do rad miejskich. Jednak część rządów państw arabskich pozostała tradycyjnie nieufna wobec inicjatywy USA, a w niektórych społeczeństwach po raz kolejny przybrały na sile nastroje antyamerykańskie. Do największych krytyków GMEI trzeba zaliczyć władze Syrii, Tunezji oraz Bahrajnu, które przypisywały Stanom Zjednoczonym działania pozorowane, służące jedynie umocnieniu dominacji i ekspansji gospodarczej USA w regionie. Pomimo głosów krytycznych 22 maja 2004 roku 22 państwa Ligi Arabskiej podpisały Deklarację z Tunisu, w której zobowiązano się do wprowadzenia reform politycznych i liberalizacji stosunków gospodarczych (Gambill, 2004, s. 47).

Konsekwencją zadeklarowanej demokratyzacji przez rządy 22 państw arabskich było ogłoszenie na szczycie państw G-8 w czerwcu 2004 roku kolejnego programu modernizacyjnego Broader Middle East and North Africa Initiative (BMENAI). Nowa forma współpracy została zaproponowana wspólnie przez Stany Zjednoczone i partnerów z Unii Europejskiej. Do BMENAI przystapiły tylko niektóre państwa regionu: Afganistan, Algieria, Bahrajn, Egipt, Jordania, Maroko, Tunezja, Turcja, Jemen oraz Irak (o genezie powołania BMENAI zobacz w: Sharp, 2005). Pośród działań ekonomicznych znalazły się zadania polityczne (wspieranie demokracji, rządów prawa oraz praw człowieka) i połączone z nimi zadania społeczno-edukacyjne (wpieranie programów rozwoju edukacji, zapewnienie swobodnego dostępu do informacji i korzystania z dostępnych źródeł wiedzy dzięki nowoczesnej technologii informacyjnej) (Broader Middle East..., 2004).

Implementacją powyższych rozwiązań miało zająć się specjalnie utworzone w tym celu Forum dla Przyszłości (Forum for the Future), na spotkaniach którego uczestnicy pod kierunkiem ministrów państw uczestniczących w BMENAI zobowiązali się omawiać realizację projektu. Forum jest ciałem koordynującym działania w ramach programu, nie zajmuje się jego realizacją czy kontrolą. Pierwsze spotkanie w ramach Forum odbyło się w Maroku w grudniu 2004 roku, rok później w Bahrajnie, a w 2006 roku w Jordanii. Podczas obrad Forum w 2004 roku budżet BMENAI ustalono na $60 \mathrm{mln}$ USD, ale z przeznaczeniem na realizację zadań z zakresu reform gospodarczych. W spotkaniach biorą udział ministrowie, liderzy polityczni, organizacje pozarządowe, przedsiębiorcy. Już pierwsze spotkanie udowodniło, iż nakłonienie rządów państw arabskich do reform o charakterze politycznym będzie budzić opór. O ile rozwiązania o charakterze ekonomicznym zaprezentowane przez Stany Zjednoczone przedstawiciele państw arabskich zaakceptowali, o tyle o zagadnienia dotyczące zmian politycznych i procesów demokratyzacyjnych były pomijane. Przyczyną było nieprzychylne stanowisko reprezentantów większości państw arabskich. Jednak Stany Zjednoczone zdecydowały się zaproponować państwom arabskim Democracy Assistance Dialogue, czyli formę spotkań przedstawicieli różnych grup społecznych z urzędnikami państwowymi. Tematyka spotkań miała dotyczyć praw i miejsca kobiet w społeczeństwie arabskim, znaczenia prawa i systemu sprawiedliwości w nowoczesnym państwie arabskim oraz transparentności działań rządzących (Sharp, 2005, s. 5).

Pomimo braku gotowości do podjęcia reform demokratyzacyjnych zdarzały się próby pozytywnych działań ze strony państw arabskich. Przykładem jest zorganizowanie 
w styczniu 2004 roku w Sanie, stolicy Jemenu międzynarodowej konferencji na temat praw człowieka, działania organizacji pozarządowych i wolnych wyborów. W efekcie spotkania uczestnicy podpisali Deklarację z Sany, która ustanawiała „Arab Democratic Dialogue Forum". Stany Zjednoczone podpisanie deklaracji przyjęły jako gotowość świata arabskiego do przeprowadzenia procesów demokratyzacyjnych z pomoca programów zewnętrznych (Sharp, 2005, s. 3). Pomimo niechęci władz państw arabskich w kwestii promocji praw człowieka partnerom transatlantyckim udało się przeforsować w 2005 roku przyjęcie projektu pod nazwą Foundation for the Future. W ramach fundacji przekazano organizacjom pozarządowym, które wspierały walkę o prawa człowieka w krajach arabskich na działalność 54 mln USD. Beneficjentami tego programu okazały się np. stowarzyszenia akademickie, które zajmowały się upowszechnianiem tematyki praw człowieka, szczególnie praw kobiet, demokracji, wolnych mediów. Kwestią sporną okazał się zapis szczegółowy, który dotyczył bezpośredniego finansowania organizacji pozarządowych przez Foundation for the Future bez pośrednictwa i kontroli tych środków ze strony administracji rządowej. W forum w 2006 roku wzięło udział 50 przedstawicieli reprezentujących ponad 100 organizacji pozarządowych z 16 państw regionu. Rangę forum podniosła obecność sekretarz stanu Condoleezzy Rice, reprezentującej Stany Zjednoczone (U.S. Department of State, Supporting Human Rights and Democracy: The U.S. Record 2006).

\section{Podsumowanie}

Na przełomie XX i XXI wieku Unia Europejska i Stany Zjednoczone skierowały do państw Bliskiego Wschodu i Afryki Północnej szereg programów pomocowych. W przypadku takich inicjatyw jak EIDHR czy HRDF zadania sprowadzały się do realizacji celów związanych z wspieraniem procesów demokratyzacyjnych i promocją rozwiązań demokratycznych w państwach regionu. Pozostałe programy, Partnerstwo Eurośródziemnomorskie, Europejska Polityka Sąsiedztwa, Broader Middle East and North Africa Initiative, The Greater Middle East Initiative, Middle East Partnership Initiative czy USAID zawierały w sobie różne cele gospodarcze, polityczne i społeczne, natomiast elementy demokratyzacyjne stanowiły jedynie ich fragment. Pomimo tych samych założonych celów (wspieranie organizacji pozarządowych, walka o prawa kobiet, rozwój edukacji, reforma systemu sprawiedliwości, pluralizm w mediach) w realizacji programów przez UE i USA można wskazać pewne różnice. UE położyła główny nacisk na reformowanie instytucji państwowych (wymiar sprawiedliwości), zwłaszcza na poziomie centralnym. Nadrzędnym celem miało być zwiększenie możliwości, sprawności działania i potencjału instytucji państwowych np. sądów. Instytucje unijne unikały finansowania partii politycznych, czynili to poszczególni członkowie UE. Przykładem jest finansowanie przez niemieckie partie siostrzanych partii w państwach regionu za pomoca różnych projektów politycznych. USA finansowały zarówno reformy demokratyczne na poziomie centralnym, jak i lokalnym. USA stawiały na decentralizację poprzez wspieranie lokalnych organów władzy i organizacje pozarządowe. Sukces w osiagnięciu zamierzonych celów Stany Zjednoczone upatrywały w pomocy w budowie zrębów społeczeństwa obywatelskiego w państwach arabskich. Wyjątkiem jest inicjatywa MEPI, w której 
aż 71\% środków przeznaczono na reformę urzędów rządowych, a organizacje obywatelskie otrzymały jedynie $18 \%$ środków finansowych. Beneficjentami programów USA były także partie polityczne. Widoczne są również różnice w promocji poszczególnych obszarów tematycznych w ramach działań demokratyzacyjnych. UE intensyfikuje swe działania w kierunku zniesienia kary śmierci, zaprzestania tortur, walczy z rasizmem i ksenofobią. USA kładą nacisk na promowanie haseł z zakresu wolności religijnej, a działania demokratyzacyjne są połączone z projektami o charakterze gospodarczym.

\section{Bibliografia}

A National Security Strategy of Engagement and Enlargement (1995), Washington D.C.

Bezpieczeństwo w Unii Europejskiej, http://europa.gery.pl/index.php?id=unia\&ue=bezp/inne/procesbar, 1.12.2014.

Broader Middle East/ North Africa Partnership, Sea Island, Georgia (2004), White House, June 9, http://www.whitehouse.gov/news/releases/2004/06/20040609-30.html, 30.09.2016.

Bush G. W. (2005), Inaugural Speech, January 20, www.2001-2009.state.gov, 12.12.2016.

Carothers T. (2005), A Better Way to Support Middle East Reform, Carnegie Endowment for International Peace, Policy Brief no. 33, February, http://www.carnegieendowment.org/files/PB33. carothers.FINAL.web, 21.04.2016.

Clinton H. R. (2010), On Developmenting the $21^{\text {st }}$ Century, speech, The Peterson Institute for International Economics, Washington D.C., January 6, http://www.state.gov/secretary/rm/2010/01/134838. html, 15.08.2012.

EIDHR (2006), Countries 2001. General Call for Proposals, www.ec.europa.eu/comm/europeaid/projects_2001_countries_en.htm, 30.03.2015.

Euro - Mediterranean Partnership/Barcelona Process, http:/ec.europa.eu/comm/external_relations/ euromed/, 2.10.2015.

EuroMed, Information and Training Seminars for Diplomats, www.euromed-seminars.org.mt/aboutems.htm, 10.12.2014.

European Commission (2003), Communication from the Commission to the Council and the European Parliament. Reinvigorating EU actions on Human Rights and Democratisation with Mediterranean Partners, www.europa.eu.int/comm/europeaid/projects/eidhr/documents_enhtm\#communications, 10.09.2013.

European Commission (2004), From MEDA I to MEDA II: Commitments and Payments, www.ec.europa.int/comm/europeaid/projects/med/financial/1995-2004.pdf, 14.03.2014.

European Commission (2005), Euro-Med Partnership. Morocco. National Indicative Programme 20052006, www.ec.europa.eu/comm/external_relations/morocco/csp/nip0506.htm, 15.05.2014.

European Commission (2006), General Budget of the European Union for the Fiscal Year 2006: The Figures, www.www.europa.eu.int/comm/budget/library/publications/budget_in_fig/syntchif_2006_en.pdf, 17.02.2015.

European Commission (2007), European Nieghbourhood Policy: Funding, www.ec.europa.eu/world/ enp/funding_en.htm, 3.12.2014.

Finkel S. E., Perez-Linan A., Seligson M. A. (2006), Effects of US Foreign Assistance on Democracy Building: Results of a Cross - National Quantitative Study.

Gambill G. C. (2004), Jumpstarting Arab Reform: The Bush Administration's Greater Middle East Initiative, "Middle East Intelligence Bulletin", vol. 6, no. 6-7.

Gershman C. (2003), A Democracy Strategy for the Middle East, National Endowment for Democracy, Dec. 12, http://www.ned.org/about/board/meet-our-president/archived-remarks-andpresentations/12122003, 10.09.2016. 
Gillespie R., Youngs R. (2002), The European Union and Democracy Promotion: The Case of North Africa, Londyn.

Girdner E. J., The Greater Middle East Initiative: Regime Change, Neoliberalism and US Global Hegemony, "Turkish Yearbook", vol. XXXVI, http://dergiler.ankara.edu.tr/dergiler/44/677/8621.pdf.

Hassan O. (2013), Constructing America's Freedom Agenda for the Middle East, New York.

Holden P. (2005), Hybrids on the rim? The European Union's Mediterranean aid policy, "Democracy", vol. 12 , no. 5 .

Huber D. (2008), Democracy Assistance in the Middle East and North Africa: a comparison of US and EU policies, "Mediterranean Politics", vol. 13, no. 1.

Kłosowicz R. (2008), U.S. Marines jako narzędzie polityki zagranicznej Stanów Zjednoczonych Ameryki, Wydawnictwo Uniwersytetu Jagiellońskiego, Kraków.

Libia zbliża się do UE (2004), „Wiadomości Europejskie”, nr 29.

Nau H. (2000), America's identity, democracy, promotion and national interest: beyond realism, beyond idealizm, w: American Democracy Promotion. Impulses, Strategies, and Impacts, red. M. Cox, G. J. Ikenberry, T. Inoguchi, Oxford.

NED, Description of 2004 Grants - Middle East and North Africa, http://www.ned.org/grants/04programs/grants-mena04.htm, 12.12.2016.

Neep D. (2004), Dilemmas of Democratization in the Middle East; The 'Forward Strategy of Freedom, "Middle East Policy Council Journal", vol. 11, no. 3.

Ośrodek Informacji i Dokumentacji Europejskiej, http://libr.sejm.gov.pl/oide/index.php?topic=newsletter\&id=newsletter_29, 13.02.2015.

Ośrodek Informacji i Dokumentacji Europejskiej: http://libr.sejm.gov.pl/oide/index.php?topic=newsletter\&id=newsletter_48, 3.03.2014.

Scott J., Steele C. (2005), Assisting democrats or resisting dictators? The nature and impact of democracy support by the United States National Endowment for Democracy, 1990-1999, "Democratization", vol. 12, no. 4.

Serwis informacyjny Wiadomości Europejskich: Więcej informacji o... (2004), „Wiadomości Europejskie", nr 48.

Serwis o Unii Europejskiej - PAP S.A. - Stosunki zewnętrzne, http://euro.pap.com.pl/europap/index. jsp?place= Menu02\&news_cat, 6.06.2014.

Sharp J. M. (2005), The Broader Middle East and North Africa: An Overview, CRS Report for Congress, February 15, 2005, Washington D.C.

Sharp J. M. (2006), U.S. Democracy Promotion Policy in the Middle East: The Islamist Dilemma, CRS Report for Congress, June 15, 2006, Washington D.C.

The MEDA System, http://ec.europa.eu/external_relations/euromed/meda.htm, 2.04.2014.

U.S. Department of State (2005), Human Rights and Democracy Fund, June 2, http://www.state.gov/g/ $\mathrm{drl} / \mathrm{c} 7607 . \mathrm{htm}, 23.10 .2016$.

U.S. Department of State (2006), Background Note: Morocco, July, http://www.state.gov/r/pa/ eibgn/5431.htm, 30.09.2012.

U.S. Department of State (2008), Report on International Religious Freedom, http://www.2001-2009. state.gov, 13.12.2016.

U.S. Department of State (2009), Advancing Freedom and Democracy Reports, May, http://www.state. gov/j/drl/rls/afdr/index.htm, 16.12.2016.

U.S. Department of State, Bureau of Democracy, Human Righs, and Labor: DRL Programs, http:// www. state.gov, 11.12.2016.

U.S. Department of State, DRL Programs: Middle East and North Africa Programs, http://www.state. $\mathrm{gov} / \mathrm{j} / \mathrm{drl} / \mathrm{p} / \mathrm{c} 29811 . \mathrm{htm}, 13.12 .2016$.

U.S. Department of State, Middle East Partnership Initiative, http://www.mepi.state.gov/, 14.09.2016. 
U.S. Department of State, Middle East Partnership Initiative. Success Stories, http://www.mepi.state. gov/c16050, 20.07.2016.

U.S. Department of State, Supporting Human Rights and Democracy: The U.S. Record, http://www. state.gov/j/drl/rls/shrd/, 20.12.2016.

U.S. Department of State, Supporting Human Rights and Democracy: The U.S. Record 2003-2004, http://www.mepi.state.gov/j/drl/rls/shrd/2003/31022.htm, 27.12.2016.

U.S. Department of State, Supporting Human Rights and Democracy: The U.S. Record 2006, http:// www.state.gov/j/drl/rls/shrd/2006/80589.htm, 15.12.2016.

USAID (2004), Morocco: Data Sheet, http://www.usaid.gov/policy/budget/cbj2006/ane/pdf/ma608013.pdf, 13.09.2012.

USAID (2005), At Freedom's Frontiers: A Democracy and Governance Strategic Framework, www. usaid.gov/our_work/democracy_and_governance/democracy_framework.html, 29.03.2014.

USAID (2006a), At Freedom's Frontiers: A Democracyand Governance Strategic Framework, http:// www.usaid.gov/our_work/democracy_framework.htm, 21.03.2016.

USAID (2006b), Primer: What We Do and How We Do It, July 14, http://www.usaid.gov/about_usaid/ primer.html, 9.07.2016.

Youngs R. (2003), European approaches to democracy assistance: learning the right lesson?, "Third World Quarterly", no. 24, vol. 1.

Zając J. (2002), Polityka Unii Europejskiej w regionie śródziemnomorskim, Torun.

Zając J. (2005), Partnerstwo Eurośródziemnomorskie, Warszawa.

\section{US and EU Democracy Assistance in the Middle East and North Africa at the Beginning of the 21st Century}

\section{Summary}

MENA is a very important region in US and EU foreign policy. Since the beginning of the 1990s, one of the crucial aspects of political involvement has been promoting democracy in the MENA region. This article presents and compares US and EU programs supporting the efforts to expand democracy in MENA countries. The main US initiatives are the following: United States Agency for International Development (USAID), Human Rights and Democracy Fund, Middle East Partnership Initiative (MEPI), The Greater Middle East Initiative as well as Broader Middle East and North Africa Initiative (BMENAI). The EU's programmes are: European Initiative for Democracy and Human Rights, EuroMediterranean Partnership and European Neighbour Policy. Both actors use similar methods but they have different approaches to achieve the goals of these initiatives.

Key words: MENA, United States, European Union, democracy 